Personal development and self-actualization of different employee generations-important key to the organizations success

\title{
Jaromíra Vaňová
}

Faculty of Materials Science and Technology in Trnava

Institute of Industrial Engineering and Management, Ulica Jána

Slovak University of Technology in Bratislava

E-mail: jaromira.vanova@stuba.sk

Slovak Republic

Peter Szabó (corresponding author)

Faculty of Materials Science and Technology in Trnava

Institute of Industrial Engineering and Management, Ulica Jána

Slovak University of Technology in Bratislava

E-mail : peter.szabo@stuba.sk

Slovak Republic

Miroslava Míkva

Faculty of Materials Science and Technology in Trnava

Institute of Industrial Engineering and Management, Ulica Jána

Slovak University of Technology in Bratislava

E-mail: miroslava.mlkva@stuba.sk

Slovak Republic

\section{ABSTRACT}

The presented paper presents the results of the project VEGA No. 1/0721/20 "Identification of priorities for sustainable human resources management for disadvantaged employees in the context of Industry 4.0 ". It focuses on the importance of personal development and self-realization for employees in industrial enterprises in the Slovak Republic about generation groups. The aim was to identify the preferences of employees in the subject area and their fulfillment by employers.

The following research methods were used to process the paper: a comparative analysis of literary sources, questionnaire survey, statistical evaluation of results using IBM SPSS 22.0 (Statistical Package for the Social Sciences), and interpretation of research results in industrial enterprises in Slovakia.

\section{Keywords: Personal development, Self-actualization, employee generations.}

\section{Introduction}

Businesses are open systems in which there is a constant exchange with the surrounding environment, from which they draw resources such as employees and to which they supply/provide their services. If they want to survive in the market, they must show a high willingness and readiness, and ability to change. New strategic directions [1], restructuring [2], and staff reductions [3] are a manifestation of the intensity of change.

According to J. Plamínek [4], it is necessary to realize that human resources are not only people but their preconditions, the potential necessary to perform actions that we humans carry.

Human capital is comprised of knowledge, skills, and practices that allow human beings to create income and other useful benefits for themselves, their employer, and society as a whole (above initial investment and operating expenses) [5]. The authors of human capital theory [6,7] accepted a formally fixed level of education as equivalent to the actual body of economically useful knowledge and skills.

Learning is motivated by 'an interconnected mix of intrinsic and extrinsic factors' Riddell [8] comments, adding 'economic instrumentalism is very far from the sole or even the main, driver of the decision to participate in adult education. Human beings are also motivated by such factors as 'the love of learning, the desire for personal growth and the urge to exert some control over future life events [9].

Adult education, at its best, provides not only improved professional skills and employability training, nor just better cultural habits but intellectual growth, transformation, and change. The debate about further education generally focuses on young adults, but in reality, adult learners a very diverse group seek to learn at different points in their lives [9].

\section{Theoretical Background}

In a simplified way, we can say that the company's performance is determined by the performance of people and 


\section{(C) Center for Promoting Education and Research (CPER) USA}

WWW.cpernet.org

processes. Process and people's performance are mutually dependent on one another. It can be hard to imagine powerful and sophisticated processes to be are processed by inefficient people [10].

For companies, people must work with advanced technologies technically, knowledge-wise but also physically (healthily) fit, able to react flexibly to changes, creative people, able to implement innovations [11].

The core elements of innovation-driven include innovations and R\&D efforts. Its developments require enough knowledge production and innovation capabilities. Moreover, it requires talents who act as the carrier of knowledge and also the foundation of innovations and R\&D. Flood, Turner, and Hannaway [12] proposed that an industry that has high knowledge contents can enhance its organizational competitiveness and those employees play the key role of value creation for the organization. Moreover, an employee's innovative behavior is a critical factor to the long-term sustainability and success of an organization. [13, 14]

The most important key to the competitiveness enhancement for an enterprise or organization to overcome the deadlock under the present highly competitive environment is whether its employees can perform innovative behavior. [14, $15]$

Organizational learning positively and significantly affects employees' overall innovation behavior, and work engagement presents mediation effects on the relationship between the two [14].

Successful personal growth requires motivation, the desire to improve, and the willingness to strive to make changes. You also need to be willing to get out of your comfort zone, and sometimes, do things that are uncomfortable, but are for your good. An open mind and the desire to learn and grow are also important.

Growth needs do not stem from a lack of something, but rather from a desire to grow as a person. Once these growth needs have been reasonably satisfied, one may be able to reach the highest level called self-actualization [16].

Self-actualization a person's desire to use all their abilities to achieve and be everything that they possibly can. The expression is used by Maslow in his theory of human motivation. (Definition of "Self-aktualization" from the [17])

According to Verešová, self-actualization is an instinctive need to fulfill one's abilities and strive to be the best one can be. Self-updating is most often interpreted as the realization of one's potentials, possibilities, or the use of one's capacity for a creative life. Maslow understands selfactualization as the self-fulfillment of the man with his meaning. It is not peace and conflict-freeness, but a constant way to be better, more perfect, more creative [18].

Self-actualization and its structural components in the system of a holistic personality have been relevant for scholars and practitioners for a long time. (A.G. Maslow, G. Allport, K.
Rogers, A.A. Bodalev, A.G. Asmolov, A.A. Derkatch, A.K. Markov, etc.) [19].

Studying this issue is important for the psychologicalpedagogical science due to the contradictions of modern society, in which only a self-actualizing person can realize oneself in the instability of economic and social spheres, actively accepting the realities of life and being capable to reflect and transform these realities within the humanist paradigm through self-understanding, self-acceptance and maximum realization of capabilities and abilities.

One of the characteristics of a person in the process of self-actualization is free-thinking and creativity. Such a personality trait gives an individual the ability to creatively relate to life in all its manifestations [19].

Companies are looking for suitable approaches to develop the potential of their employees and are willing to invest their resources in this area. Individual learning is important as a basis for corporate collective learning. What the employee learns should be available to other employees of the company [11].

Knowledge transfer in multi-generation teams, between employees in different stages in their professional careers, means both provisions of new knowledge to an employee and increase of knowledge thanks to the knowledge and experience already possessed by receivers [20].

Intergenerational learning is a generational phenomenon in the workplace that is of particular interest to human resource development. It concerns individuals' joint construction of knowledge through an exchange of information with one or more individuals from different generations [21].

As stated by [22], one of the emerging challenges in Industry 4.0 is the changes in the workplace demographic. The admission of the younger generation in the workplace presents a new challenge on the ability to transfer knowledge, mainly because of their characteristic differences with the older generation already settled in the workplace. If not treated correctly, this condition could incapacitate an organization's capability to retain and at the same time expand its knowledge base [23].

Generational differences are likely to determine what individuals want from their work, what kind of workplace environment is wished for, and how organizations can satisfy these wants and desires [24].

\section{Methodology}

The questionnaire is one of the most commonly used methods in research. It is used to collectively and quickly find out facts, opinions, attitudes, preferences, values, motives, needs, and interests [25]. For the above reasons, we chose the questionnaire in our survey as a tool for data collection.

The research sample consisted of employees of all generational groups, which are currently represented in the labor market in the Slovak Republic. The survey was conducted from May 2018 to January 2019. The questionnaire 


\section{(C) Center for Promoting Education and Research (CPER) USA}

WwW.cpernet.org

contained 40 questions, of which 8 were open-ended and others contained a range of different answering options that the respondent could identify. Due to the scope, only some questions were selected and evaluated to process this paper.

The research methods - IBM SPSS 22.0 (Statistical Package for the Social Sciences) was used to summarize, process, and analyze the obtained data. Basic statistical characteristics (absolute and relative frequency, average, median, modus, and standard deviation) were used to evaluate the results. Descriptive statistics tools (tables, graphs) were used to interpret the data.

\section{The research questions $(R Q)$ :}

RQ 1: What importance do different generations of employees attach to the factors of personal development and self-actualization?

RQ 2: How do different generations of employees in industrial companies perceive the fulfillment of the factor of personal development and self-actualization?
RQ 3: What are the differences between the importance and fulfillment of the factors of personal development and selfactualization in employees of different generations in industrial enterprises in the Slovak Republic?

\section{Result and discussion}

A total of 534 respondents from all over Slovakia took part in the research. The research sample $(\mathrm{N}=534)$ consisted of employees of industrial enterprises, where the automotive industry has the largest share (30.7\%), engineering industry + production $(29.6 \%)$, electrical engineering $(6.6 \%)$, food industry (5.8\%), information technology (3.4\%). Table 1 shows the composition of respondents according to the size of the enterprise in which they are employed, with respondents from enterprises with more than 500 employees and respondents from medium-sized industrial enterprises (51-250 employees) having the largest representation. $48.9 \%$ of men and $51.1 \%$ of women took part in the research, so we can state an equal representation of both sexes in the research.

Table 1: Composition of the respondents according to the enterprise size (own elaboration, 2019)

\begin{tabular}{|l|c|c|}
\hline Enterprise size & $\begin{array}{c}\text { Absolute } \\
\text { frequency }\end{array}$ & $\begin{array}{c}\text { Relative } \\
\text { frequency (\%) }\end{array}$ \\
\hline 1-10 employess & 32 & 5,99 \\
\hline 11-50 employess & 66 & 12,36 \\
\hline 51-250 employess & 105 & 19,66 \\
\hline 251-500 employess & 68 & 12,73 \\
\hline More than 500 employess & 263 & 49,25 \\
\hline Total & $\mathbf{5 3 4}$ & $\mathbf{1 0 0 , 0 0}$ \\
\hline
\end{tabular}

The composition of respondents based on generational can say that the composition of respondents corresponds to the groups is shown in Table 2. It is clear from the table that the composition of generational groups in the labor market in the composition between generational groups is uneven, but we Slovak Republic.

Table 2: Composition of the respondents according to generation group (own elaboration, 2019)

\begin{tabular}{|l|c|c|}
\hline Generation group & Absolute frequency & Relative frequency (\%) \\
\hline Baby boomers & 36 & 6,74 \\
\hline Generation X & 153 & 28,65 \\
\hline Generation Y & 323 & 60,49 \\
\hline Genaration Z & 22 & 4,12 \\
\hline Total & $\mathbf{5 3 4}$ & $\mathbf{1 0 0 , 0 0}$ \\
\hline
\end{tabular}

From the point of view of employee job positions, the largest part consists of administrative and technical-economic employees (40.4\%), specialists (23.3\%), management employees $(18.5 \%)$, production employees $(9.6 \%)$, and others $(7.9 \%)$. The composition of the respondents in terms of educational attainment was $0.7 \%$ with primary education, $38.0 \%$ secondary education, and $61.3 \%$ university education.

RQ1: What importance do different generations of employees attach to the factors of personal development and self-actualization? 
Table 3 presents the observed average values and classification scale for different generations. Respondents from standard deviations of the importance of the factor of personal the BB and $\mathrm{Z}$ generations show a difference in the importance development and self-actualization for different generations of of the examined factors. Generation BB attaches more employees in industrial enterprises. The importance of these importance to self-actualization, but in generation $\mathrm{Z}$ we state factors was assessed on a 5-point scale, from a minimum(1) to the opposite assignment of importance, they attach more a maximum (5) value. The overall average value of the importance to personal development. For generations $\mathrm{X}$ and $\mathrm{Y}$, importance of the personal development factor is 4.30 and at the responses are more balanced and the degree of variability self-actualization is 4.12 . From the average values, it is clear to of responses is lower. what extent the above factors are important on the 5-point

Table 3: The importance of analysed factors for various generations of employees

\begin{tabular}{|l|c|c|c|c|c|c|c|c|}
\hline \multirow{2}{*}{$\begin{array}{l}\text { Factors - } \\
\text { importance }\end{array}$} & \multicolumn{2}{|c|}{ Baby boomers } & \multicolumn{2}{c|}{ Generation X } & \multicolumn{2}{c|}{ Generation Y } & \multicolumn{2}{c|}{ Generation Z } \\
\cline { 2 - 8 } & Average & Std.Dev. & Average & Std.Dev. & Average & Std.Dev. & Average & Std.Dev. \\
\hline $\begin{array}{l}\text { Personal } \\
\text { development }\end{array}$ & 3,78 & 1,045 & 4,14 & 0,899 & 4,44 & 0,713 & 4,23 & 1,020 \\
\hline $\begin{array}{l}\text { Self- } \\
\text { actualization }\end{array}$ & 4,17 & 0,845 & 4,14 & 0,877 & 4,11 & 0,814 & 3,95 & 1,090 \\
\hline
\end{tabular}

RQ2: How do different generations of employees in previous finding (Table 3) indicates a lower fulfillment of industrial companies perceive the fulfillment of the factor of these factors by employers than the employees would like. personal development and self-actualization?

From the average values, it is clear to what extent the above

Table 4 shows the average values and standard factors are met on the 5-point classification scale for different deviations of the fulfillment of the factor of personal generations. The degree of variability in the perception of the development and self-actualization for different generations of fulfillment of the examined factors personal development and employees in industrial enterprises. The total average value of self-actualization is higher than in the attribution of the fulfillment of the personal development factor is 3.19 and importance. at self-actualization, it is 3.37 , which in comparison with the

Table 4: The fulfillment of analysed factors for various generations of employees

\begin{tabular}{|l|c|c|c|c|c|c|c|c|}
\hline \multirow{2}{*}{$\begin{array}{l}\text { Factors - } \\
\text { fulfilment }\end{array}$} & \multicolumn{2}{|c|}{ Baby boomers } & \multicolumn{2}{c|}{ Generation X } & \multicolumn{2}{c|}{ Generation Y } & \multicolumn{2}{c|}{ Generation Z } \\
\cline { 2 - 9 } & Average & Std.Dev. & Average & Std.Dev. & Average & Std.Dev. & Average & Std.Dev. \\
\hline $\begin{array}{l}\text { Personal } \\
\text { development }\end{array}$ & 3,17 & 1,000 & 3,12 & 1,118 & 3,25 & 1,066 & 2,91 & 1,342 \\
\hline Self-actualization & 3,42 & 1,052 & 3,28 & 1,060 & 3,41 & 0,988 & 3,41 & 1,054 \\
\hline
\end{tabular}

RQ3: What are the differences between the During the processing of the research results, interesting importance and fulfillment of the factors of personal findings concerning individual generations were found. The development and self-actualization in employees of different results of the research are also presented in graphical form for generations in industrial enterprises in the Slovak Republic? better illustration (Figures 1 and 2).

For each of the analyzed factors, a more detailed analysis was performed to evaluate the third research question. 


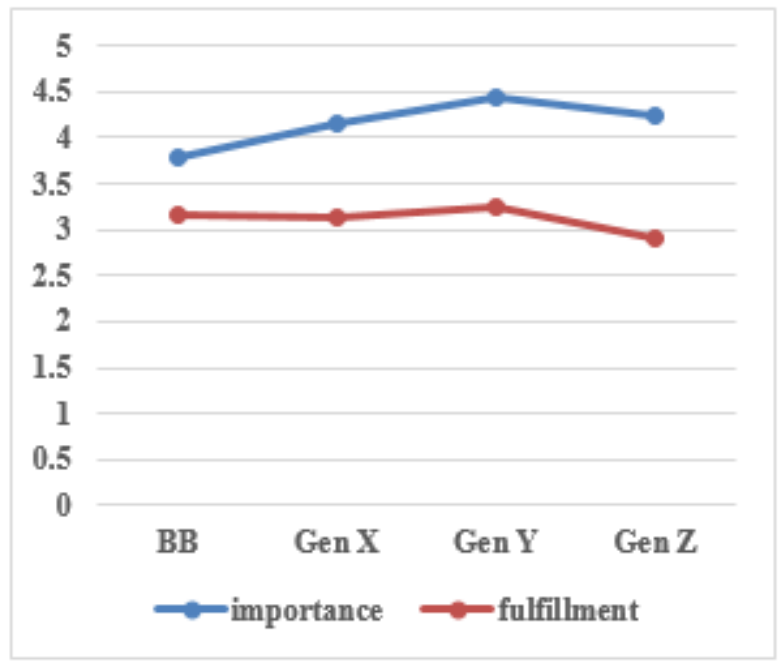

Figure 1: Factor - Personal development

Personal development (Figure 1): Based on the results of the research, it can be stated that personal development is the most important factor for Generation Y. The oldest generation of Baby Boomers does not consider this factor so important, which is understandable as the representatives of this generation have mostly reached the peak of their careers. As for the fulfillment of this factor, the lowest level is declared by Generation Z, which may be related to entering the labor market, with the representatives of this generation still looking for their place in it.

Self-actualization (Figure 2): Based on the results of the research, it can be stated that self-actualization is an important factor for all groups of generations (range 4.17 -

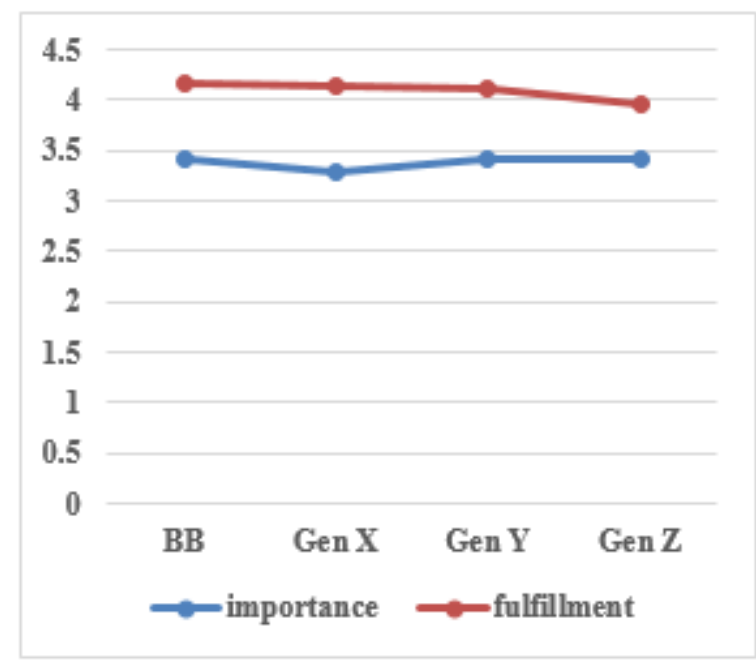

\section{Figure 2: Factor-Self-actualization}

3.95). The differences between the importance and the fulfillment of this factor are almost the same for all generational groups. Generation $\mathrm{X}$ respondents are the least satisfied with the fulfillment of the self-actualization factor.

The survey was focused on finding out whether employees feel or met the preference of a certain age group when supporting personal growth. For this reason, we asked the respondents in the questionnaire survey: "Which age categories of employees are preferred in education in your organization?" On the other hand, 37\% of respondent's state that younger employees are preferred in education. The results of the answers to this question are shown in Figure 3.

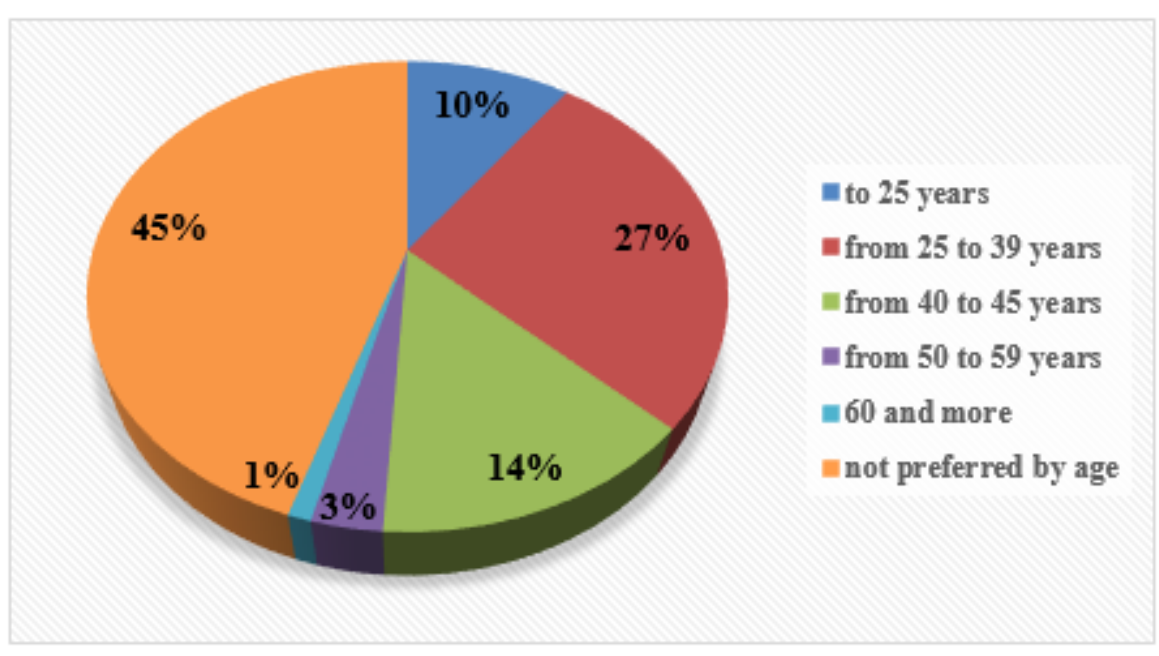

\section{Conclusion}

Figure 3: Preference of employees in education with regard to age categories
From the findings of the research, it can be stated that the factors of personal growth and self-realization are important for employees, but they are not sufficiently fulfilled according to their expectations by employers. In business practice, management should make more use of investment https://ijbassnet.com/ opportunities in human resource development. Within incentive programs, it is one of the ways to fulfill the ambitions and expectations of its employees. Not only according to our findings but also in connection with known motivational theories, such as Maslow's hierarchy of needs. Each generation has its characteristics, which in human 


\section{(C) Center for Promoting Education and Research (CPER) USA}

WWW.cpernet.org

resources management company management should be considered.

Our findings, even when confronted with the opinions and findings of other authors, can be considered relevant and their consideration can help in business practice in the effective management of human resources.

Age awareness must be developed, particularly among HR managers and staff representatives at all levels, if organizations are to develop a corporate climate sensitive to demographic change and with a positive attitude towards aging [26].

"On the issue of the importance of human capital and education, Becker in [27] stated the following theoretical facts:

- Income is generally an increasing function due to a person's age (albeit at a declining rate).

- The unemployment rate is inversely proportional to the level of skills.

- Young people change jobs more frequently, and therefore acquire knowledge and learn on the job; at the same time, they receive more training than their older colleagues. "

In addition, as younger workers tend to demonstrate higher growth-related motives, and older workers tend to show higher generativity related motives [28, 29], younger workers may be perceived as able and willing to receive knowledge to develop themselves, while older workers may be recognized as the ideal knowledge senders, who aim to benefit others [3032].

The finding that older workers are expected to contribute their knowledge, but might not be considered appropriate knowledge recipients by their colleagues, might have detrimental effects on older workers' perceived developmental opportunities. As these opportunities are important for many older workers who wish to develop their knowledge and skills until retirement [33, 34], organizations should be careful not to disregard older workers when creating opportunities for development [32].

A WEF survey of international businesses [35] showed that the world's largest employers do not have any desire to retrain each one of their workers to help and increased competition. The corporate sector is ready to invest in training only for its most productive employees, and even in such cases, the expectation is for them to take their initiative. The rest of the workforce will likely shift to freelance and temporary employment $[36,37]$.

The Mincer earnings function, in which salary is a function of education and work experience, has become the main instrument for assessing the effectiveness of investments in human capital. It is important to note that this function gives greater weight to specific human capital as compared to the general: the $\log$ of salary equals the sum of the linear function of years of schooling and the square function of work experience [36, 38, 39].

Modern economies require people to invest in acquiring knowledge, skills, and information not only when they are young, but for most of their lives.

Acknowledgment

The paper is a part of project VEGA No. 1/0721/20 ,Identification of priorities for sustainable human resources management for disadvantaged employees in the context of Industry 4.0 ".

\section{References}

HOHBERGER, J., ALMEIDA, P., PARADA, P.: The direction of firm innovation: The contrasting roles of strategic alliances and individual scientific collaborations. Research policy, 44(8), pp. 1473-1487, 2015.

doi: 10.1016/j.respol.2015.04.009.

HOWARD, J. L., FRINK, D. D.: The effects of organizational restructure on employee satisfaction. Group \& Organization Management, 21(3), pp. 278-303, 1996. doi: 10.1177/1059601196213003.

VUTA, D. R., FARCAS, A.: The role of training in organizational and employee development. Land Forces Academy Review, 20(3), pp. 367-372, 2015.

PLAMÍNEK, J.: Sebeřizení. Praktický atlas managemntu cílu a stresu. Grada Publishing, a.s. Praha 2004.

KUZMINOV Y., FRUMIN I.: Dvenadtsat' reshenii dlya novogo obrazovaniya: doklad Tsentra strategicheskikh razrabotok $i$ Vysshei shkoly ekonomiki [Twelve Solutions for a New Education: Report by the Center for Strategic Research and the Higher School of Economics] (eds. Y. Kuzminov, I. Froumin), Moscow: HSE (in Russian), 2018.

KUZMINOV YA., SOROKIN P., FROUMIN I.: Generic and Specific Skills as Components of Human Capital: New Challenges for Education Theory and Practice. Foresight and STI Governance, vol. 13, no 2, pp. 19 -41, 2019. doi: 10.17323/2500-2597.2019.2.19.41.

SAKALAS, A., LIEPE, Z.: Human Capital and it's Measurement Insight Attitudes. Economics and Management. Kaunas University of Technology. Kaunas: Technologija, 15, pp. 726-732, 2010. doi: 10.5755/j01.ee.24.3.2787. 
RIDDELL, S.: Conclusion: the role of lifelong learning in reducing social inequality at a time of economic crisis. . In Riddell, S., Markowitsch, J. and Weedon, E. (Eds.), (2012) Lifelong Learning in Europe: Equity and Efficiency in the Balance, Bristol: The Policy Press (pp. 151-162). doi: 10.1332/policypress/ 9781447300137.003.0008

CLANCY, S. L., HOLFORD, J.: "Life-changing things happen" The role of residential education in the transformation of adults' learning and lives. Education+ Training, 60(6), 620-636, 2018. doi: 10.1108/ET-03-2018-0069

GYURÁK BABELOVÁ, Z., VAŇOVÁ, J., PRAJOVÁ, V.: Strategic management and organization performance in the context of quality management systems. Quality. Production. Improvement: production engineering. No 2(9), pp. 16-42, 2018. doi: 10.30657/qpi.2018.09.02

VODÁK, J., KUCHARČÍKOVÁ, A.: Efektivní vzdelávaní zaměstnancu, Grada Publishing, a.s. Praha, 2007.

FLOOD, P. C., TURNER, T., HANNAWAY, C.: Attracting and retaining knowledge employees: Irish knowledge employees and the psychological contract. Dublin: Blackhall, 2000.

JANSSEN, O.: Job demands, perceptions of effort-reward fairness and innovative work behavior. Journal of Occupational and Organizational Psychology, 73(3), 287-302, 2000. doi: 10.1348/096317900167038

HSIU-CHUAN L., YUAN-DUEN L.: A Study of the Influence of Organizational Learning on Employees' Innovative Behavior and Work Engagement by a Cross-Level Examination, EURASIA Journal of Mathematics Science and Technology Education ISSN: 1305-8223 (online) 1305-8215 (print) 2017 13(7):3463-3478.

doi: 10.12973/eurasia.2017.00738a

PIETERSE, A. N., KNIPPENBERG, D. V., SCHIPPERS, M., STAM, D: Transformational and transactional leadership and innovative behavior: The moderating role of psychological empowerment. Journal of Organizational Behavior, 31(4), 609-623, 2010. doi: 10.1002/job.650

Maslow's Hierarchy of Needs. [Online], Available: https://www.simplypsychology.org/maslow.html

Self-actualization. Cambridge Business English Dictionary, [Online],

Available: https://dictionary. cambridge.org/dictionary/english/self-actualization

VEREŠOVÁ, M. a kol. Sociálna psychológia - človek vo vzt’ahoch. Enigma Publishing s.r.o., 2011.

KOLPAKOVA N.: Self-actualization and formation of the civic position of students of pedagogical specialties. The European Proceedings of Social \& Behavioural Sciences. pp. 908-915, 2018. doi: 10.15405/epsbs.2019.04.98

SIPA, M.: Management of an Intergenerational Cooperation-Effect of Company Size. The European Proceedings of Social \& Behavioural Sciences, pp. 182-193, 2017. doi: 10.15405/epsbs.2017.12.02.16

GERPOTT, F. H., LEHMANN-WILLENBROCK, N., VOELPEL, S. C.: A phase model of intergenerational learning in organizations. Academy of Management Learning \& Education, 16(2), 193-216, 2017. doi: 10.5465/amle.2015.0185

HECKLAU, F., GALEITZKE, M., FLACHS, S., KOHL, H.: Holistic approach for human resource management in Industry 4.0, Procedia Cirp, 54(1), 1-6. 2016. doi: 10.1016/j.procir.2016.05.102

ARTHA, W. I. K., SUZIANTI, A., ARDI, R.: Knowledge management in multi-generation workforce: investigation on critical success factor and strategy. MATEC Web of Conferences. Vol. 218. EDP Sciences, 2018.. doi: 10.1051/matecconf/201821804010

MAIER, T., TAVANTI, M., BOMBARD, P., GENTILE, M., BRADFORD, B.: Millennial generation perceptions of value-centered leadership principles, Journal of Human Resources in Hospitality \&Tourism, Vol. 14 No. 4, pp. 382 397, 2015. doi: 10.1080/15332845.2015.1008386

GAVORA, P., a kol.: Elektronická učebnica pedagogického výskumu, Bratislava 2010, Univerzita Komenského.

NAEGELE, G., WALKER, A.: A guide to good practise in age management. Dublin/Ireland: European Foundation for the Improvement of Living and Working Conditions, 2006 [E-Reader Version]. Retrieved from http://www.eurofound.europa.eu/pubdocs/2005/137/en/1/ef05137en.pdf 
TIRUNEH, M. W., ŠTEFÁNIK, M., a kol.: Trh práce na Slovensku: analýzy a prognózy. Bratislava: Ekonomický ústav SAV. 2014. Retrieved from: http://www.ekonom.sav.sk/uploads/journals/261_monografia-trh-prace-na-slovensku.pdf ERIKSON, E. H.: Childhood and society. New York, NY: Norton. 1963.

KOOIJ, D., DE LANGE, A. H., JANSEN, P., DIKKERS, J.: Older workers' motivation to continue to work: Five meanings of age: A conceptual review. Journal of Managerial Psychology, 23(4), pp. 364-394, 2008. doi: 10.1108/02683940810869015.

DEAL, J. J., ALTMAN, D. G., ROGELBERG, S. G. Millennials at work: What we know and what we need to do (if anything). Journal of Business and Psychology, 25(2), 191-199, 2010. doi: 10.1007/s10869-010-9177-2

VOELPEL, S., SAUER, A., \& BIEMANN, T.: Career planning for mid-and late-career workers. In J. W. Hedge \& W. C. Borman (Eds.), The oxford handbook of work and aging (pp. 503-519). Oxford, UK New York, NY: Oxford University Press, 2012. doi: 10.1093/oxfordhb/9780195385052.013.0153

BURMEISTER, A., FASBENDER, U., DELLER, J.: Being perceived as a knowledge sender or knowledge receiver: A multistudy investigation of the effect of age on knowledge transfer. Journal of Occupational and Organizational Psychology, 91(3), pp. 518-545, 2018. doi: 10.1111/joop.12208

ARMSTRONG-STASSEN, M., \& STASSEN, K.: Professional development, target-specific satisfaction, and older nurse retention. Career Development International, 18(7), pp. 673-693, 2013. doi: 10.1108/CDI-08-2013-0102

VAN VIANEN, A. E. M., DALHOEVEN, B. A. G. W., DE DE PATER, I. E.: Aging and training and development willingness: Employee and supervisor mindsets. Journal of Organizational Behavior, 32(2), pp. 226-247, 2011. doi: 10.1002/job.685

The Future of Jobs. Available at: https://www.weforum.org/reports/the-future-of-jobs-report-2018, accessed 19.01.2019

KUZMINOV YA., SOROKIN P., FROUMIN I.: Generic and Specific Skills as Components of Human Capital: New Challenges for Education Theory and Practice. Foresight and STI Governance, vol. 13, no 2, pp. 19-41, 2019. doi: 10.17323/2500-2597.2019.2.19.41

The Global Human Capital Report.

Available at: http://www3.weforum.org/docs/WEF_Global_Human_Capital_Report_2017.pdf, accessed 19.01.2019

MINCER J.: Schooling, Experience, and Earnings, Cambridge, MA: National Bureau of Economic Research. 1974.

PSACHAROPOULOS G., PATRINOS H.A. Returns to investment in education: A decennial review of the global literature. Education Economics, vol. 26, no 5, pp. 445-458, 2018. doi: 10.1080/09645292.2018.1484426 